\title{
USING LEAN GOVERNMENT IN IMPROVEMENT OF THE SERVICES IN PUBLIC ADMINISTRATION ON THE EXAMPLE OF MARSHAL'S OFFICE IN LUBUSKIE VOIVODESHIP
}

\author{
ANNA LUDWICZAK \\ University of Zielona Góra, POLAND \\ e-mai: a.ludwiczak@wez.uz.zgora.pl
}

RECEIVED

ACCEPTED

JEL

CLASSIFICATION

KEYWORDS

ABSTRACT
14 July 2017

15 December 2017

$\mathrm{H} 40, \mathrm{H} 83$

Lean government, Value Stream Mapping, public administration, public services, grant application

The aim of the article is to present the possibilities of using lean government for improving services in Polish public administration. The first part of the article outlines the specifics of public services. Then the essence of lean management was discussed and also the examples of its use in public administration in the world. The final part of the article presents the case study of lean government implementation to improve the selected processes. The study was processed using the value stream mapping tool (VSM). The solutions to eliminate process waste and main barriers to streamlining action are presented.

\section{Introduction}

In the Polish public administration a trend, aimed at improving both effectiveness and efficiency of its functioning, has been observed for many years. On the ground of Polish public administration, quality management systems compliant with the requirements of ISO 9001 became particularly popular. This is mainly due to them that in Polish public administration procedural approach was implemented and the striving for continuous improvement 
of quality of service in accordance with the PDCA cycle. Literary research (Bugdol, Pakuła, 2017; Flieger, 2013; Ludwiczak, 2014) show that in many cases the application of a procedural approach in the Polish public administration does not produce the expected results. Among the most important obstacles to application of this orientation are legal regulations, functional organizational structure, lack of decision-making powers at the lower levels of the organizational structure, insufficient knowledge of the essence and implementation of the process approach can be pointed out. Difficulties in process management occur especially in large units of public administration, which include the provincial governments. The services implemented by Marshall offices, as executive bodies of provincial governments, are characterized by diversity and complexity. Due to large social groups and organizations, which are the recipients of these services, it is difficult to identify the customers and their requirements. One of the process oriented concepts, focused on creation customer value at the same time, is lean government. The aim of the article is to present possibilities of using lean management in the improvement of the services in Polish public administration.

\section{Literature overview}

Lean government is translation of popular in private equities concept of Lean management into public administration. So the essence of lean management is so called "Lean thinking" allowing for, according to Womack and Jones: defining value, optimal ordering of activities that create value, performing activities that create a stream of values without interruption at the time the customer requests the demand, gradual increase in effectiveness of implemented activities (Womack, Jones, 2001). It is therefore about planning and then continuously improving value stream so as to provide the customer with the expected value in the possibly most effective way.

Lean government concept has gained huge popularity in the public sector in the world, but in Poland, among public managers, it is still unnoticed. Many public institutions in the USA have an experience in using it, including Fort Wayne (Graham, 2006), city of Peoria and McHenry in Illinois, Conroe in Texas, Palm Bay, Florida, Cincinnati and Montgomery in Ohio and Pitkin Country in Colorado (Kavanagh, 2010). Programs that increase the efficiency and productivity of work, resulting from the basic assumptions of Lean management, have also gained great popularity among others in Great Britain, Australia and New Zealand (Grycuk, 2011). Numerous examples of positive effects of lean management in the context of streamlining processes in public administration can be found in the literature. Most of these studies are conducted in the form of case studies (Demel, 2013; Di Pietro et al., 2013; Hasenjager, 2006; Kavanagh, 2010; Krings et al., 2006, Maarse, Janssen, 2012; Randor, 2010; Waterman, McCue, 2012). The research of the above mentioned authors suggests that the use of lean government can contribute to improving the functioning of processes, especially those that have very complex nature such as public procurement. By identifying waste in processes, the time and cost of implementing them can be significantly reduced. Furthermore, by stabilizing and standardizing value streams, it is possible to reduce the number of errors.

Despite many advantages of using lean government, the researchers point out the problems emerging during the implementation. Maarse and Janssen note that lean is focused only on efficiency and customer value creation and does not take into account the public values. So there is focus on creating customer (citizen) value and it neglects to create value for the democratic system (Maarse, Janssen, 2012). Randor points out that many public administration employees in the investigated offices had the feeling that lean was being imposed and that staff direct-dealing with customer service had nothing to say in its execution. The employees paid attention to increased productivity and error reduction, but there was lack of focus on customer needs and motivation (Randor, 2010). It is 
therefore important to find the answer to the question how to manage and engage employees in lean organization improvement. In turn Arfmann and Federico think, that weakness of lean is its maladjustment to service specification (Arfmann, Federico, 2014).

The value of applying lean government concept in Polish public administration is indicated by Krasiński (Krasiński, 2011) and Nogalski, Czerska and Klimek (Nogalski et al., 2010), who comes to the conclusion that the key actions to improve the work of the office are to focus on investigating the causes of problems, eliminating waste, improving internal communication, and delegating authority. In Polish public administration there is still lack of practical examples of implementation of the discussed concept.

\section{Method of study}

To perform the purpose of the study, a qualitative research was conducted in the form of a case study. The study was based on the interviews with the staff involved in the process and on documentation studies. The study was conducted by using Value Stream Mapping tool. For the purpose of analysis, standard graphical symbols were used to adjust some of them to the specificity of the administrative processes. Data tagging applied in the process:

- P/T (Process Time) - time of actual execution of the activity, ie. actual verification of the submitted application by the employee,

- L/T (Lead Time) - time necessary to move one application through the process from the beginning to the end (actions + breaks, interruptions),

- C/O (Changeover Time) - time, for example, to file a single application and prepare to verify another application,

- \% C/A - number of positively completed negotiations, opinions, agreements, etc.

Prior to the study, the employees were presented with its goal, and it was explained to them what is the lean government concept and what for is the mapping tool. After creation of the current state map together with the employees working on the process, the workshop was held, where the improvement plan was drafted and barriers to improvements were identified. One of the most important processes implemented by the Marshal's offices is the execution of tasks commissioned by the governmental authorities in the area of regional development. For the purpose of this study, one of the processes has been chosen to conduct a grant competition for municipalities to develop or update revitalization programs. This task is characterized by a high degree of complexity, involves more than one organizational unit and its client is the Ministry of Regional Development, that the provincial government has concluded the agreement with. The general course of value stream is shown in Figure 1.

Due to the high degree of complexity of the process and its execution time, which was envisaged in the contract for more than 23 months, two processes were selected for further analysis: recruitment and evaluation of the applications and the contracts preparation, which were highlighted in Figure 1. In the examined process, besides the provincial government and the Ministry of Development, local governments of the Lubuskie voivodeship, which are beneficiaries of the aid, participate. They can be treated on the one hand as suppliers (they provide grant applications) and as a specific type of a customer (they support the launch of processes aimed at revitalizing degraded areas by helping to prepare revitalization programs). 


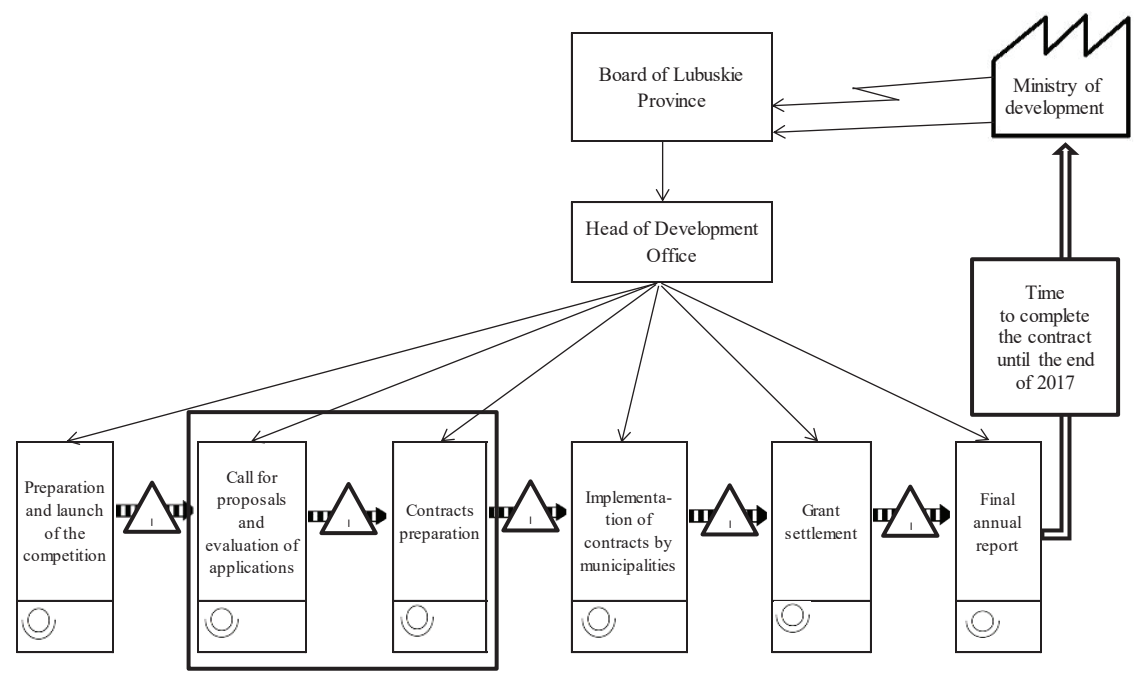

Figure 1. Map of value stream for conducting a grant contest for municipalities to develop or update revitalization programs Source: own study based on surveys.

\section{Study resullts}

The analysis of value stream from the moment of grant call to signing the grant agreement for a randomly selected application has shown that the overall lead time $(\mathrm{L} / \mathrm{T})$ is 95 days and 1.5 hours, while process time $(\mathrm{P} / \mathrm{T})$ is 28 hours and 5 minutes. This means that value adding activities in the process represent $3.7 \%$ of process time. The remaining time of transition consists of waiting for the documents to be processed further, unnecessary transport between organizational units, or waiting time during the exchange of correspondence with the municipality. An analysis of the current state map, made by the author and the team of employees involved in the process under investigation, has highlighted the places where waste is occurring.

The first noted problem was the long waiting time of the application during the formal and substantive evaluation. It was the result of using batch processing in the office, ie. only after the end of the competition the formal assessment of the applications was started, and the substantive assessment was launched only after the formal evaluation was completed (Figure 2). This resulted in total waiting time of 51.5 days for the analyzed proposal until the start of negotiations with the municipality about the amount of the budget, while the value added activities in the process $(P / T)$ were 17 hours.

As a streamlining solution it was proposed to combine the formal and substantive assessment into the continuous flow area. Prior to the change, the formal evaluation of all applications was handled by two employees, who then joined the team working on substantive evaluation. Additionally, according to MRR requirements, each application was substantially evaluated by two-pair eye, ie. the evaluation was made by two independent employees, what additionally increased waiting time for evaluation of particular applications. Once the changes have been made, the proposal, which will be positively evaluated positively, will immediately be submitted for substantive evaluation and, if necessary, to the negotiation. The change will shorten the evaluation time for applications by approximately 5 days (i.e. the time needed for a formal assessment with the involvement of two full-time employees). 


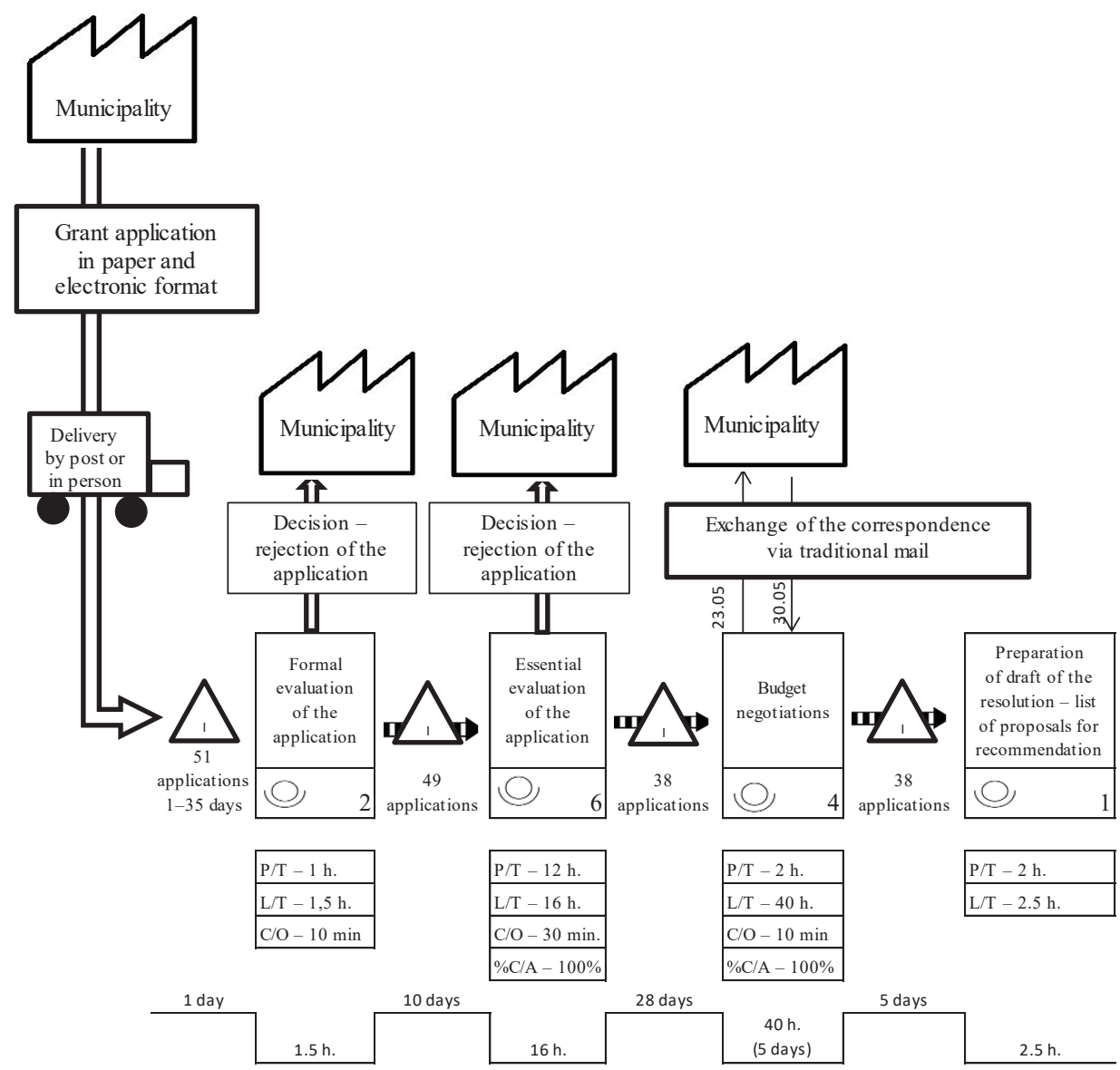

Figure 2. Part of value stream map concerning the evaluation of the grant application

Source: own study based on surveys.

Another waste observed during the analysis of the current state map is the improper processing, to which Lisiecka and Burka count, among others, as inadequate or outdated technologies (Lisiecka, Burka, 2015). The term can also refer to the distribution channels through which communication with the customer takes place.

Figure 3 shows three parts of value stream map showing the exchange of documents and information between the municipality and the Marshal's Office. It can be seen that each time the waiting time from the time of sending the information to receiving the reply via traditional mail took from 5 to 8 days. Replacing traditional mail by sending information electronically can reduce waiting time by approximately 4 to 6 days.

The third identified waste was over-processing when contract was approved by the lawyer, as shown in Figure 4. 

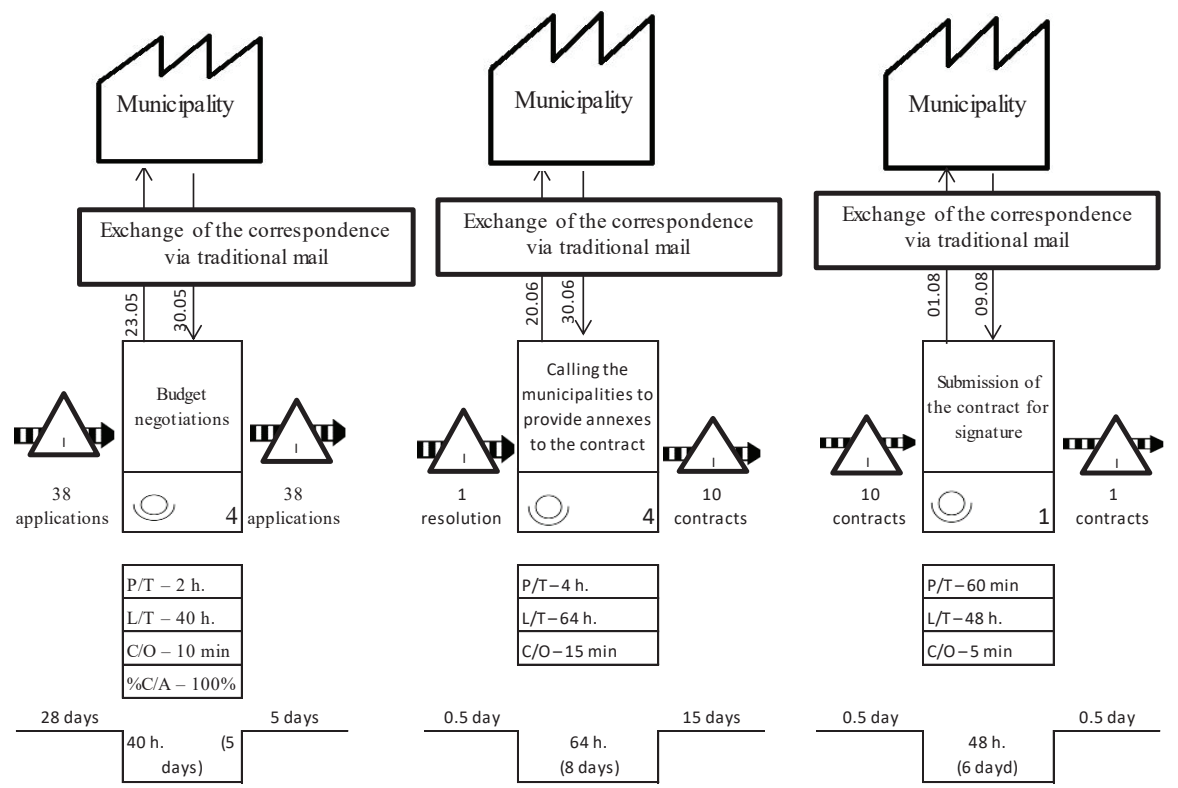

Figure 3. Three parts of value stream map showing the time devoted to the exchange of information between the municipality and the Marshal's Office

Source: own study based on surveys.
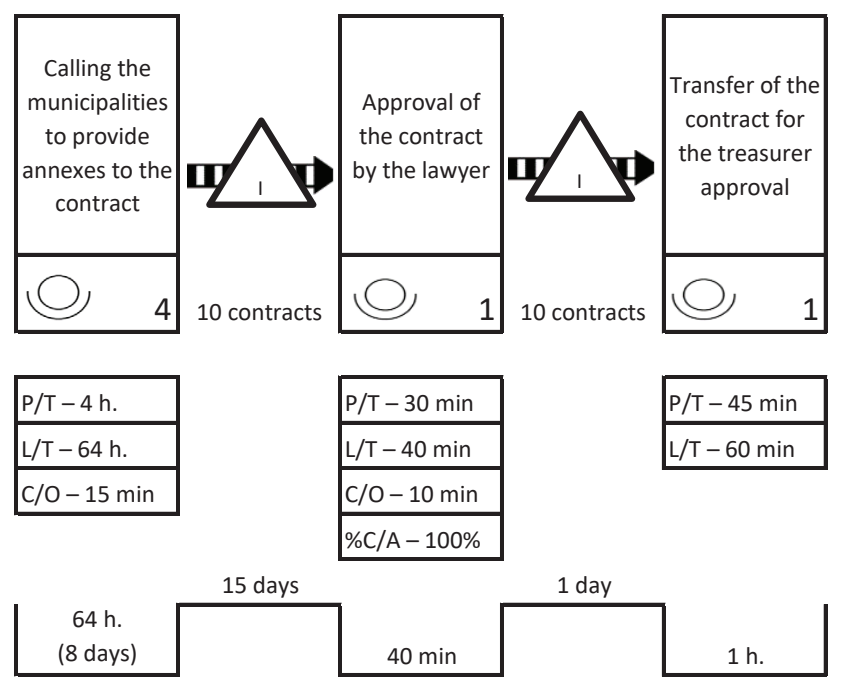

Figure 4. Part of value stream map concerning the contract approval by the lawyer

Source: own study based on surveys. 
The interview shows that the lawyer reviews and approves the contract draft with the beneficiaries (municipalities) before signing the contract with the Ministry of Development (and before the call announcement). Reconsidering the contract identical to a previously approved by the lawyers draft can be regarded as duplication of the same operation and this step can be eliminated.

The fourth noted waste is over processing when the treasurer approves the contract, which is shown in Figure 5.

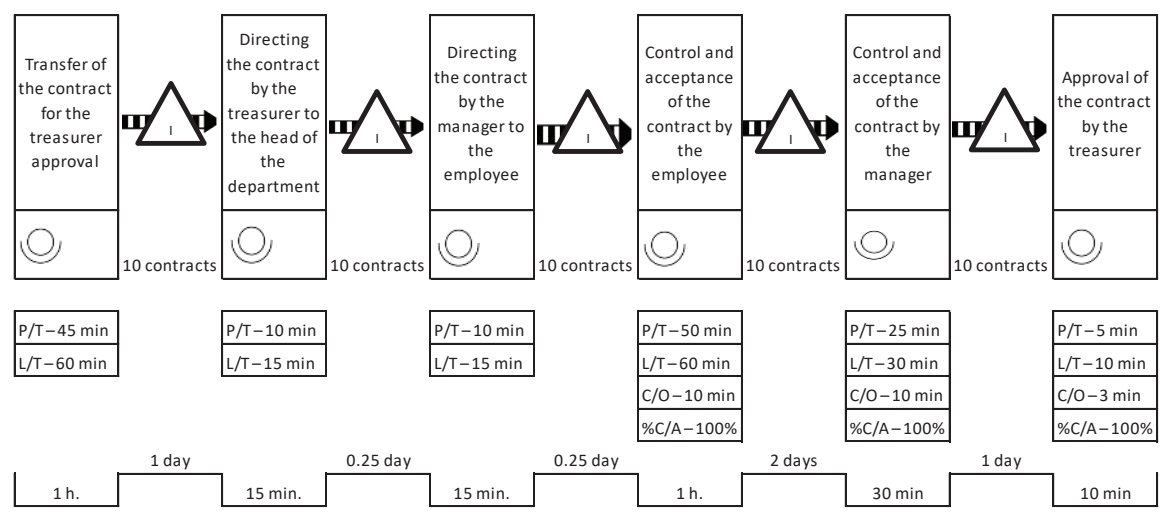

Figure 5. Part of value stream map concerning the contract approval by the treasurer

Source: own study based on surveys.

In the investigated office, with regard to the existing functional organizational structure, communication between the departments and the offices is formalized. Before the particular case is assigned to the substantive employee, the following path is followed: secretariat - director - secretariat - manager - employee. Employee empowerment can be used to solve this problem, that is empowering the contract auditor to approve the contract on behalf of the treasurer. This would reduce the path of the document circulation (reducing unnecessary transportation) and as a result shorten process time and breaks between the processing steps.

In addition, during the analysis of the map, attention was paid to the changeover time $(\mathrm{C} / \mathrm{O})$, which, in the case of administrative processes, is time spent on completing and postponing the documents, whose processing was completed and preparing another batch of documents before processing them. In order to improve the system of the workplace, which would contribute to reducing the changeover time, the use of $5 S$ technique was recommended.

Presented above suggestions for improvement are the first stage of enhancement and do not close the possibilities of the further development of the process. They were developed on the base of the current state of human and material resources at the development office (eg. project supervisors -3 employees involved in the project at $50 \%$ working time and 1 employee at $100 \%$ working time) and taking into account the parallel processes. The following obstacles (barriers) hindering or impeding improvements have been identified during the analysis:

1. Too detailed guidance on how to implement the competition imposed by the Customer (the Ministry of Development) in the contract.

2. Legal regulations and internal procedures for the document circulation. 
3. Functional organizational structure and low level of emproverment.

4. Little flexibility in the scope of employees' responsibilities, limiting, for example, the possibility of adding more overloaded organizational units to the employees from other departments.

5. Lack of interest in shortening the process time justified by employees' long implementation deadlines set out in the agreement with the Ministry of Development.

In the case of the last barrier, it was noted that the staff engaged in the process of defining customer requirements focused exclusively on the Ministry of Development, so the institution entrusted to them. They did not, however, take into account the needs and expectations of the communities for which the shorter service time could have been important.

\section{Conclusions}

In conclusion, using lean government in Polish public administration can improve efficiency of its operation and increase customer satisfaction (for example, shorten service delivery time or improve communication channels). Nevertheless, one should be aware that implementation of this concept involves breaking down legal, organizational and human attitudes barriers. The example of applying lean government presented in this paper requires further research in the scope of usefulness of this concept in Polish public administration.

\section{References}

Arfmann, D., Federico, G. (2014). The Value of Lean in the Service Sector: A Critique of Theory \& Practice. International Journal of business and Social Sciences, 2 (5), 18-24.

Bugdol, M., Pakuła, G. (2017). Korzyści wynikające ze stosowania podejścia procesowego zgodnego z nową normą ISO 9001 w realizacji usług administracyjnych. Problemy Jakości, 2, 22-27.

Demel, S. (2013). Embracing 'lean' - It's all about the process, Hottopics [strategic sourcing], February/March 2013.16.

Di Pietro, L., Mugion, R.G., Renzi, M.F. (2013). An integrated approach between Lean and customer feedback tools: An empirical study in the public sector. Total Quality Management \& Business Excellence, 24, 7-8.

Flieger, M. (2013). Dojrzałość procesowa gmin w świetle współczesnych paradygmatów zarządzania publicznego: zastosowanie zarządzania procesowego w urzędach gmin - wyniki badań. Nierówności Społeczne a Wzrost Gospodarczy, 35, 113-123.

Graham, A.R. (2006). Performance Is the Best Politics: How to Create High-Performance Government Using Lean Six Sigma. Fort Wayne: HPG Press.

Grycuk, A. (2011). Lean Government, czyli koncepcja szczupłego zarządzania w administracji publicznej. Analizy BAS, 3 (47), 1-9.

Hasenjager, J. (2006). Lean government (is not an oxymoron). A Connecticut Agency in efficiency's court. Industrial Engineer, July.

Kavanagh, S.C. (2010). Less Time, Lower Cost, and Greater Quality: Making Government Work Better with Lean Process Improvement. Chicago: Government Finance Officers Association.

Krasiński, M. (2011). Koncepcja kaizen w jednostce samorządu terytorialnego. In: M. Przybyła (ed.), Nauki o zarządzaniu (pp. 89-98). Wrocław: Wydawnictwo Uniwersytetu Ekonomicznego we Wrocławiu.

Lisiecka, K., Burka, I. (2015). Źródła powstawania marnotrawstwa w organizacjach na przykładzie usługowych przedsiębiorstw ciepłowniczych. Studia Ekonomiczne. Zeszyty Naukowe Uniwersytetu Ekonomicznego w Katowicach, 233, 75-89.

Ludwiczak, A. (2014). Podejście procesowe a skuteczność usług w administracji publicznej. In: R. Kucęba, E. Kulej-Dudek, P. Pypłacz, K. Smoląg (eds.), Koncepcje zarządzania współczesnymi organizacjami (pp. 68-77). Sekcja Wydawnicza Wydziału Zarządzania Politechniki Częstochowskiej.

Maarse, N., Janssen, M. (2012). The Need to Adjust Lean to the Public Sector. In: H.J. Scholl M. Janssen, M.A. Wimmer, C.E. Moe, L.S. Flak (eds.), Electronic Government (pp. 54-65). Heidelberg: Springer. LNCS 7443.

Radnor, Z. (2010). Transferring Lean into government. Journal of Manufacturing Technology Management, 3 (21), 411-428. 
Waterman, J., McCue, C. (2012). Lean Thinking within Public Sector Purchasing Department: The Case of the U.K. Public Service. Journal of Public Procurement, 4 (12), 505-527.

Womack, J.P., Jones, D.T. (2001). Odchudzanie firm. Eliminacja marnotrawstwa kluczem do sukcesu. Warszawa: Centrum Informacji Menedżera.

Cite this article aS: Ludwiczak, A. (2018). Using lean government in improvement of the services in public administration on the example of Marshal's Office in Lubuskie voivodeship. European Journal of Service Management, 2 (26), 145-153. DOI: 10.18276/ejsm.2018.26-18. 